\title{
Internal standard addition calibration: Determination of calcium and magnesium by atomic absorption spectrometry
}

\author{
Felipe Manfroi Fortunato ${ }^{a}$, Marcos A. Bechlin ${ }^{a}$, José A. Gomes Neto ${ }^{\mathrm{a}, *}$, George L. Donati ${ }^{\mathrm{b}}$, Bradley T. Jones ${ }^{\mathrm{b}}$ \\ a São Paulo State University-Unesp, Analytical Chemistry Department, P.O. Box 355, 14801-970 Araraquara, SP, Brazil \\ ${ }^{\mathrm{b}}$ Department of Chemistry, Wake Forest University, Winston-Salem, NC 27109, USA
}

\section{A R T I C L E I N F O}

\section{Article history:}

Received 4 March 2015

Received in revised form 9 April 2015

Accepted 9 April 2015

Available online 16 April 2015

\section{Keywords:}

Internal standard addition calibration

Precision

Accuracy

\begin{abstract}
A B S T R A C T
Internal standard addition (ISA) is a new calibration method that combines the principles of internal standardization and standard additions. The current work demonstrated the effectiveness of ISA for the determination of Ca and Mg in biodiesel samples and certified reference materials (CRMs) by flame atomic absorption spectrometry. Manganese and $\mathrm{Sr}$ were selected as internal standards for Mg and Ca, respectively. Results for Ca and Mg in CRMs using ISA were in agreement with certified values at the 95\% confidence level ( $t$-test). The relative standard deviations $(n=12)$ were $\mathrm{ca} .6 \%$ for both analytes. For comparison purposes, $\mathrm{Ca}$ and $\mathrm{Mg}$ were also determined by the traditional methods of external standard calibration (ES), standard additions (SA) and internal standardization (IS). Recoveries obtained with ISA (Ca: 93-109\%; Mg: 100-106\%) were similar to those found with IS (Ca: 100-112\%; Mg: 98-105\%), but significantly better than ES (Ca: 219-291\%; Mg: 111-120\%) and SA (Ca: 97-127\%; Mg: 106-128\%). Results for Ca and Mg determined in biodiesel and CRMs using ISA were more accurate and more precise than those obtained with ES, SA and IS.
\end{abstract}

(C) 2015 Elsevier B.V. All rights reserved.

\section{Introduction}

Except when an absolute method of determination is available, choosing the most adequate calibration strategy is essential in any quantitative chemical analysis [1]. Among the main calibration methods employed in quantitative instrumental analysis, the most important are the external standard calibration (ES), standard additions (SA) and internal standardization (IS) [2]. The first one is the simplest, but it is the most susceptible to errors caused by fluctuations in operating conditions and/or matrix effects. On the other hand, SA and IS can minimize these errors, significantly improving accuracy and precision [3].

The standard addition method is useful when the analyte is present in a complex matrix and the matrix-matching approach cannot be used [4]. However, it presents some limitations: (i) spiked analyte concentrations must be within the linear working range; (ii) species of spiked analyte and sample analyte must be similar; (iii) it is time-consuming (convenient for a small number of samples); and (iv) large sample volumes are required to prepare a series of standard solutions, restricting its application in some cases.

The IS method has been used to minimize errors caused by instrumental drift and to reduce chemical matrix effects. It combines the straightforwardness of ES without the need for matrix-matching.

\footnotetext{
* Corresponding author. Tel.: + 551633019611.

E-mail address: anchieta@iq.unesp.br (J.A.G. Neto).
}

However, the selection of an adequate internal standard species that presents similar physical-chemical properties to the analytes is not a trivial task. Moreover, the element selected as internal standard must be absent, or occur at very low concentrations in the samples [5,6].

Some works in the literature have combined the benefits of SA and IS by plotting the analyte-to-internal standard signal ratio as instrumental response (the so-called analytical signal) versus the added concentration of analyte to the sample. In this case, the internal standard species is added to all series of sample solutions at a known and fixed concentration [7,8]. It is important to mention that the pre-requisites for the selection and use of an internal standard are also valid here, which sometimes can be considered restrictive for a large scale routine analysis.

Standard dilution analysis (SDA) is a new calibration method recently proposed in the literature [9] that combines the principles of IS and SA. The theory and equations of the SDA method were adapted to the internal standard addition (ISA) calibration employed in this work. In SDA, a solution containing the analytical sample and a standard mixture containing the analyte and an internal standard (solution 1 ) is mixed with another solution also containing the analytical sample and the blank (solution 2). As solution 1 is diluted by solution 2 in the same container, many calibration points are generated on-the-fly. Because the amount of analytical sample never changes (both solutions 1 and 2 have $50 \%$ of sample), a matrix-matching is obtained and only the standard solution is in fact diluted. The observed analyte signal $\left(S_{A}\right)$ will result from the quantity present in the sample (sam) and the 


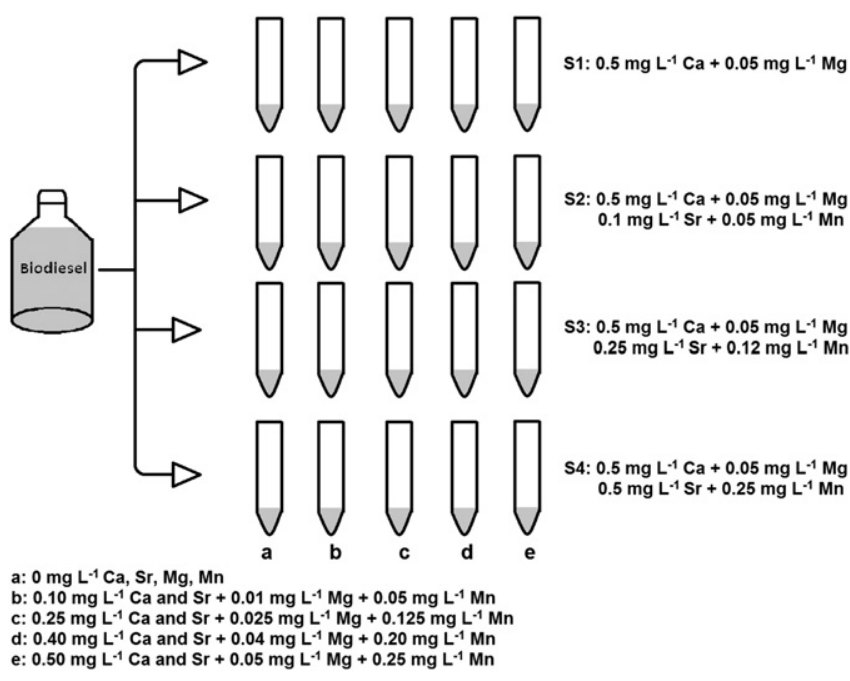

Fig 1. Scheme of sample preparation to evaluate the performance of the ISA method spiked with different concentrations of $\mathrm{Sr}$ and $\mathrm{Mn}$.

concentration of added standard (std). On the other hand, the observed internal standard signal $\left(\mathrm{S}_{\mathrm{I}}\right)$ will come from the standard solution alone. The obtained signals are related to the concentrations by the calibration sensitivity $(\mathrm{m})$ of the respective calibration curve equations, $\mathrm{S}_{\mathrm{A}}=\mathrm{m}_{\mathrm{A}} \mathrm{C}_{\mathrm{A}}$ and $S_{I}=m_{I} C_{I}$. While applying the SDA method, one uses the ratio of the analyte to internal standard signals according to Eq. (1) [9]:

$\frac{\mathrm{S}_{\mathrm{A}}}{\mathrm{S}_{\mathrm{I}}}=\frac{\mathrm{m}_{\mathrm{A}} \mathrm{C}_{\mathrm{A}}^{\mathrm{std}}}{\mathrm{m}_{\mathrm{I}} \mathrm{C}_{\mathrm{I}}}+\frac{\mathrm{m}_{\mathrm{A}} \mathrm{C}_{\mathrm{A}}^{\mathrm{sam}}}{\mathrm{m}_{\mathrm{I}} \mathrm{C}_{\mathrm{I}}}$.

If the term $\left(S_{A} / S_{I}\right)$ is plotted versus $\left(1 / C_{I}\right)$, a linear relationship is obtained, where intercept and slope will be $\left(\mathrm{m}_{A} \mathrm{C}_{A}^{\text {std }} / \mathrm{m}_{\mathrm{I}} \mathrm{C}_{\mathrm{I}}\right)$ and $\left(\mathrm{m}_{\mathrm{A}} \mathrm{C}_{\mathrm{A}}^{\text {sam }} / \mathrm{m}_{\mathrm{I}}\right)$, respectively. Because $\mathrm{C}_{A}^{\text {std }} / \mathrm{C}_{\mathrm{I}}$ is known from the preparation of solution 1 , the analyte concentration in the sample is easily found by applying Eq. (2).

$C_{A}^{\text {sam }}=\frac{\text { slope }}{\text { intercept }} \times \frac{C_{A}^{\text {std }}}{C_{I}}$.

As described above, SDA is carried out using only two solutions. To further confirm the SDA hypothesis, we have applied ISA to the determination of $\mathrm{Ca}$ and $\mathrm{Mg}$ by flame atomic absorption spectrometry in five biodiesel samples and in certified reference materials (CRMs) of milk, botanical tissues, biological tissues, flours and biodiesel. All samples and CRMs were also analyzed by comparative calibration methods (ES, SA and IS) to check the performance of ISA. It is important to note that different from SDA, the application of ISA requires the preparation of several standard calibration solutions;
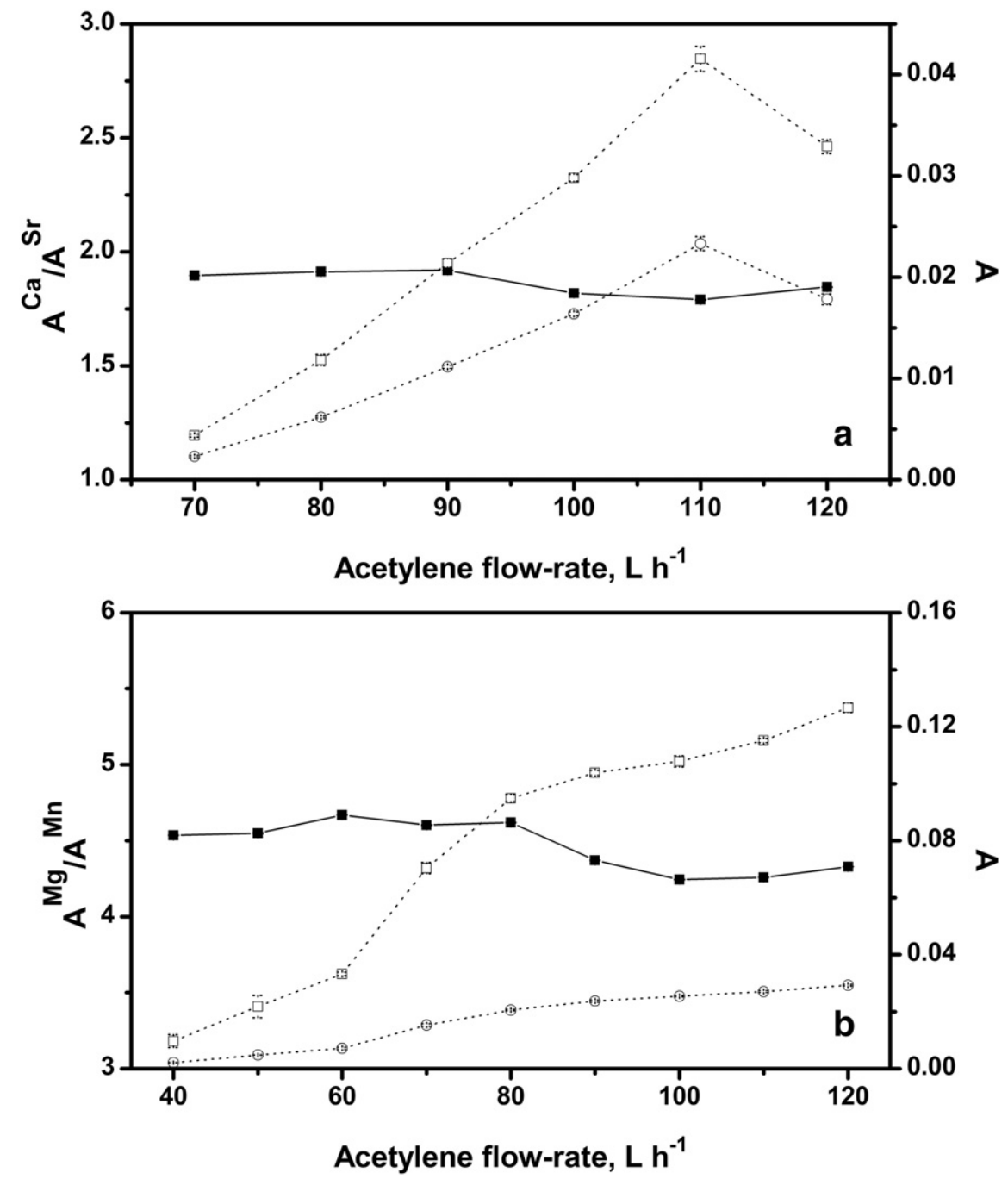

Fig 2. Influence of variation of acetylene flow-rate on: a) $A^{\mathrm{Ca}}(\square) A^{\mathrm{Sr}}(\bigcirc)$ and $A^{\mathrm{Ca}} / A^{\mathrm{Sr}}$ ratio $(\mathbf{\square})$; b) $A^{\mathrm{Mg}}(\square) A^{\mathrm{Mn}}(\bigcirc)$ and $A^{\mathrm{Mg}} / \mathrm{A}^{\mathrm{Mn}}$ ratio $(\square)$ 

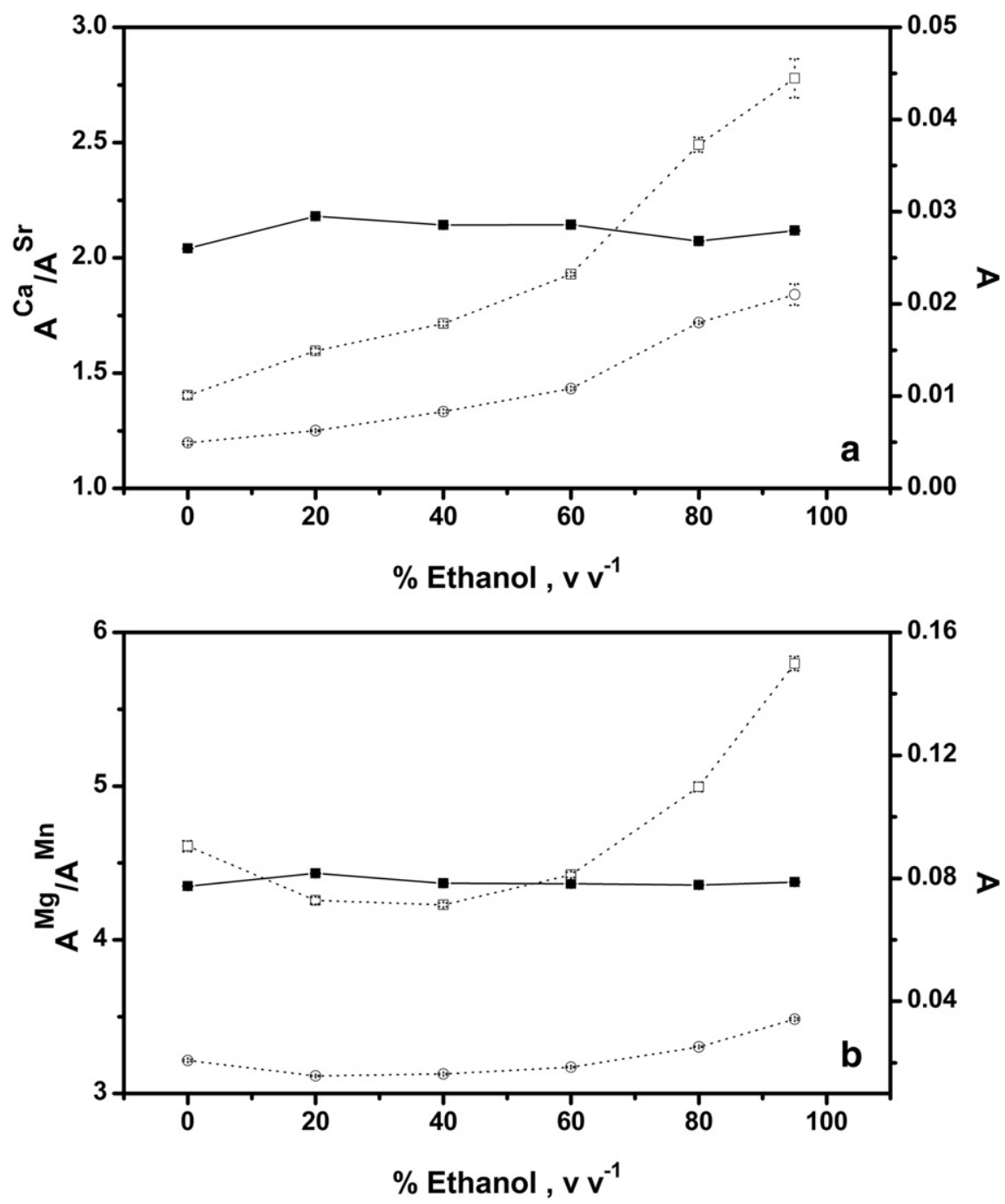

Fig 3. Effects of ethanol on: a) $A^{\mathrm{Ca}}(\square) A^{\mathrm{Sr}}(\bigcirc)$ and $A^{\mathrm{Ca}} / \mathrm{A}^{\mathrm{Sr}}$ ratio $(\mathbf{\square})$; b) $A^{\mathrm{Mg}}(\square) A^{\mathrm{Mn}}(\bigcirc)$ and $A^{\mathrm{Mg}} / \mathrm{A}^{\mathrm{Mn}}$ ratio $(\boldsymbol{\square})$

similar to the traditional methods of SA or IS. In this case, the goal of this study is to demonstrate that in addition to its application on-thefly, as with SDA, the basic principle of combining SA and IS may also be applied by preparing different standard calibration solutions, as with ISA.

\section{Materials and methods}

\subsection{Instrumentation}

A ContrAA 300 high-resolution continuum source flame atomic absorption spectrometer (Analytik Jena, Jena, Germany) was employed in all measurements. An air-acetylene flame was used for Ca, Mg, Mn and $\mathrm{Sr}$ atomization. Acetylene with 99.7\% purity (Air Liquid, São Paulo, Brazil) was used as fuel gas at a flow-rate of $80 \mathrm{~L} \mathrm{~h}^{-1}$. All measurements were carried out ( $n=7)$ at the most sensitive lines for Ca (422.672 nm), $\mathrm{Mg}(285.212 \mathrm{~nm})$ and $\mathrm{Sr}(460.733 \mathrm{~nm})$, and at secondary lines for $\mathrm{Ca}$ (239.855 nm), Mg (202.582 nm) and $\mathrm{Mn}(279.826 \mathrm{~nm})$. The optimized operating conditions were: $5.0 \mathrm{~mL} \mathrm{~min}{ }^{-1}$ sample introduction rate, $7 \mathrm{~mm}$ observation height and wavelength-integrated absorbance (WIA) equivalent to 3 pixels (central pixel \pm 1 ; central pixel corresponds to measurement at core line).
Microwave-assisted acid digestion was applied to all samples using an Anton Paar Multiwave 3000 (Graz, Austria) with a rotor of 48 reaction PFA vessels (internal volume of $50 \mathrm{~mL}$ ).

\subsection{Reagents and analytical solutions}

High purity deionized water obtained using a Millipore Rios $5 \circledR$ reverse osmosis and a Millipore Milli- $\mathrm{Q}^{\mathrm{TM}}$ Academic ${ }^{\circledR}$ deionizer system (resistivity $18.2 \mathrm{M} \Omega \mathrm{cm}$, Millipore, Bedford, USA) was used to prepare all solutions.

Analytical solutions were prepared by appropriate dilution of $1000 \mathrm{mg} \mathrm{L}^{-1} \mathrm{Ca}, \mathrm{Mg}$, Mn and Sr atomic absorption spectroscopic standards (SpecSol, São Paulo, Brazil). All solutions were acidified to $1 \%(v / v) \mathrm{HNO}_{3}$ (JT Baker, Phillipsburg, USA).

Ethanol-water solutions containing 0-95\% $(v / v)$ ethanol were prepared by appropriated dilution from distilled ethanol.

A $5 \%(\mathrm{~m} / \mathrm{v})$ La stock solution was prepared by dissolving $58.6 \mathrm{~g}$ of $\mathrm{La}_{2} \mathrm{O}_{3}$ (Merck, Darmstadt, Germany) in $250 \mathrm{~mL}$ of hydrochloric acid (Spectrum, Gardena, USA) and further dilution to $1000 \mathrm{~mL}$ with deionized water.

All solutions were stored in high-density polypropylene flasks (Nalgene, Rochester, USA). Plastic flasks and glassware materials were 


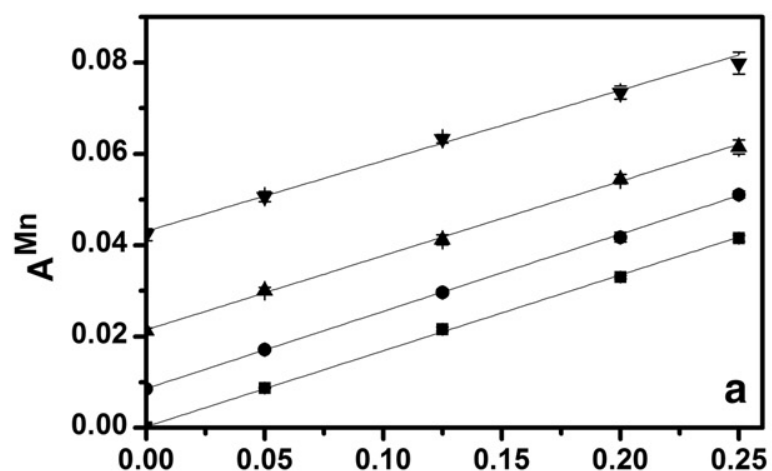

[Mn], $\mathrm{mg} \mathrm{L}^{-1}$
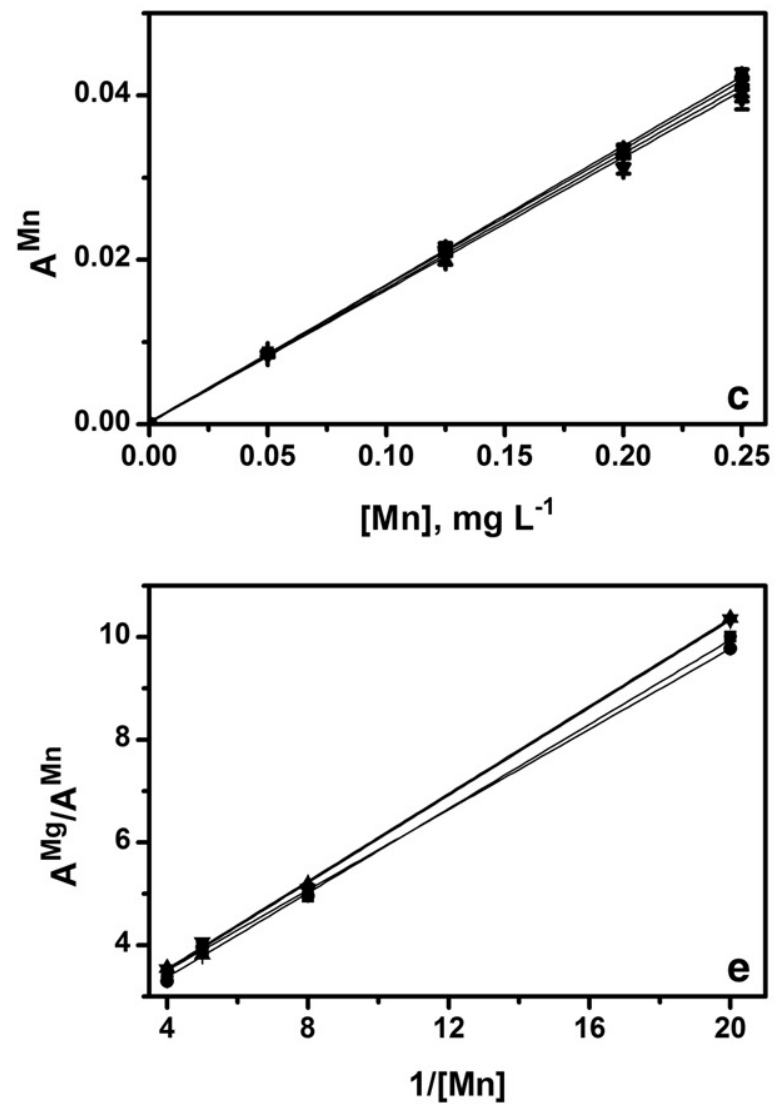

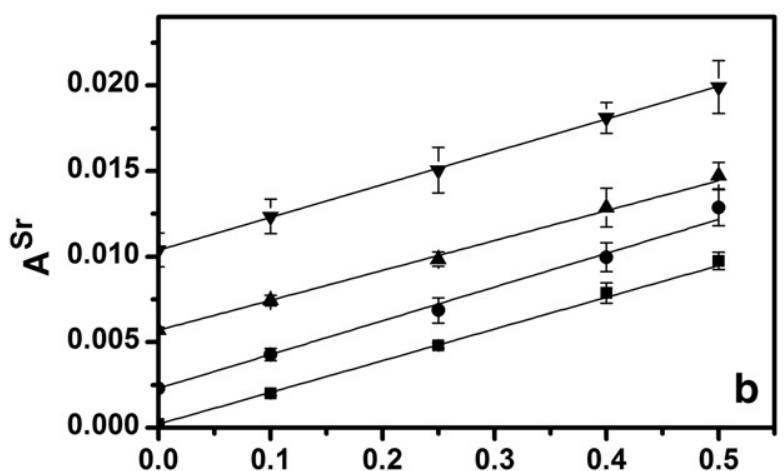

[Sr], $\mathrm{mg} \mathrm{L}^{-1}$

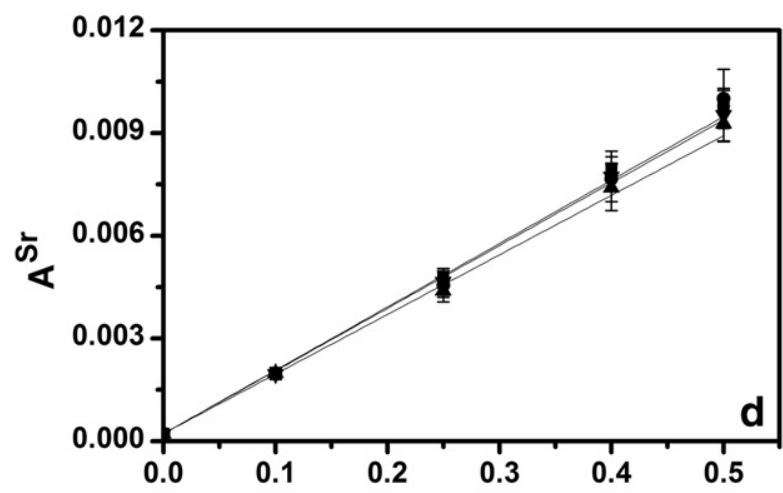

[Sr], $\mathrm{mg} \mathrm{L}^{-1}$

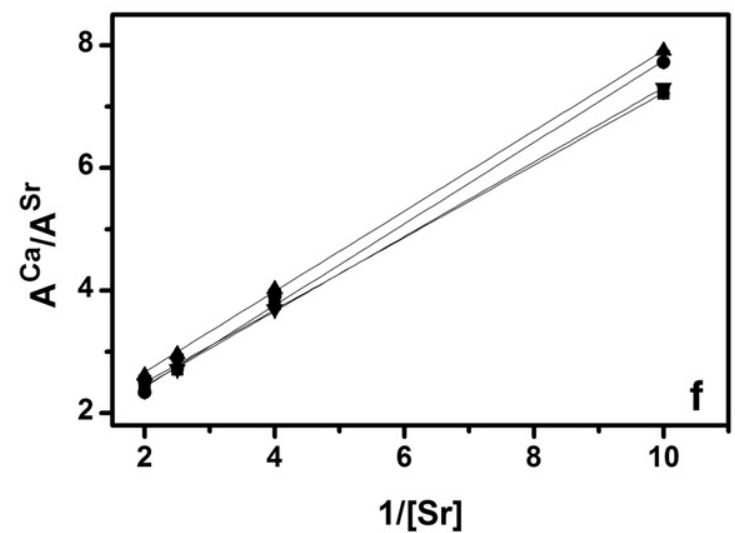

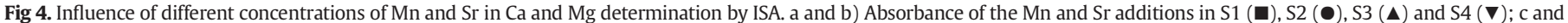
d) discounted absorbance of the Mn and Sr additions in S1-S4; e and f) ISA curves to Mg and Ca using the discounted absorbance values of Mn and Sr.

cleaned by soaking in $10 \%(v / v) \mathrm{HNO}_{3}$ for at least $24 \mathrm{~h}$, and then rinsing abundantly in deionized water before use.

\subsection{Sample preparation}

Biodiesel samples provided by the Monitoring and Research Center of Fuel Quality, Biofuels, Oil and Derivatives (CEMPEQC, Araraquara, Brazil) were stored in amber glass flasks in a refrigerator (about $5{ }^{\circ} \mathrm{C}$ ) before analysis. Approximately $1.0 \mathrm{~g}$ of biodiesel samples and Biodiesel Standard Oil (Conostan, Baie-D'Urfé, Canada) were weighed directly into a polypropylene tube (Corning, New York, USA) and diluted with $5 \mathrm{~mL}$ of distilled ethanol. Then, $100 \mu \mathrm{L}$ of $\mathrm{HNO}_{3}$ and $200 \mu \mathrm{L}$ of La stock solution were added and the volume was brought to $10 \mathrm{~mL}$ with distilled ethanol [10,11].

Certified reference materials of Apple Leaves (1515), Tomato Leaves (1573a), Rice Flour (1568a), Wheat Flour (1567a), Non-Fat Milk Powder (1549), Whole Milk Powder (8435), Bovine Liver (1577b), and
Mussel Tissue (2976) from the National Institute of Standards and Technology (Gaithersburg, USA) were prepared by microwave-assisted acid digestion. Approximately $0.2 \mathrm{~g}$ of samples was accurately weighed and transferred to microwave flasks. Aliquots of $3.0 \mathrm{~mL}$ of $\mathrm{HNO}_{3}, 1.0 \mathrm{~mL}$ of $30 \%(v / v) \mathrm{H}_{2} \mathrm{O}_{2}$ (Merck, Darmstadt, Germany) and $2.0 \mathrm{~mL}$ of deionized water were then added and the mixtures were submitted to the following optimized 5-step heating program: (1) $15 \mathrm{~min}$ from 0 to $600 \mathrm{~W}$; (2) $5 \mathrm{~min}$ at $600 \mathrm{~W}$; (3) $15 \mathrm{~min}$ from 600-800 W; (4) $5 \mathrm{~min}$ at $800 \mathrm{~W}$ and (5) $20 \mathrm{~min}$ at $0 \mathrm{~W}$ (cooling). After digesting and cooling, the resulting solutions were transferred to $25 \mathrm{~mL}$ volumetric flasks and diluted to the mark with deionized water.

\subsection{Analytical procedure}

Manganese [12] and Sr [13-15] were selected as internal standards for $\mathrm{Ca}$ and $\mathrm{Mg}$, respectively. The effectiveness of $\mathrm{Mn}$ and $\mathrm{Sr}$ as internal 


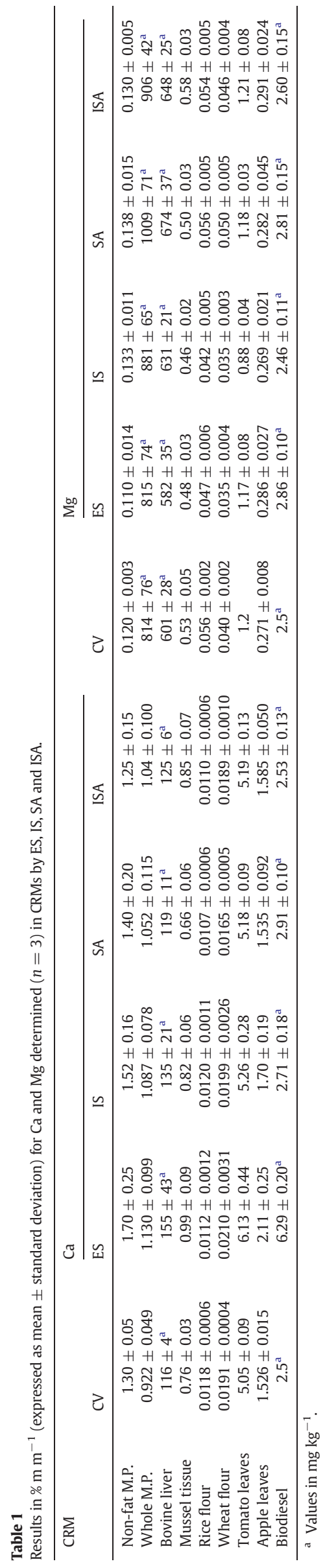

standards to correct interferences caused by different atomization conditions was evaluated by measuring the absorbance of solutions containing $0.1 \mathrm{mg} \mathrm{L}^{-1} \mathrm{Mg}, 0.2 \mathrm{mg} \mathrm{L}^{-1} \mathrm{Mn}$, and $0.5 \mathrm{mg} \mathrm{L}^{-1}$ of both $\mathrm{Ca}$ and Sr. In this study, different flame stoichiometry conditions (acetylene flow-rate varied in the $40-120 \mathrm{~L} \mathrm{~h}^{-1}$ range) and ethanol-water compositions (ethanol in deionized water varied in the $0-95 \% v / v$ range) were evaluated.

Considering that both internal standards selected may be present in the original samples, the influence of their concentrations on the ISA performance was also evaluated by analyzing one biodiesel sample spiked with different concentrations of Mn and Sr. Twenty solutions containing approximately $1.0 \mathrm{~g}$ of biodiesel sample $(\mathrm{S})$ were prepared and divided into four groups (S1-S4) of 5 solutions (Fig. 1). Each group contained different internal standards concentrations and fixed concentrations of analytes: $0.5 \mathrm{mg} \mathrm{L}^{-1} \mathrm{Ca}+0.05 \mathrm{mg} \mathrm{L}^{-1} \mathrm{Mg}(\mathrm{S} 1)$; $0.5 \mathrm{mg} \mathrm{L}^{-1} \mathrm{Ca}+0.05 \mathrm{mg} \mathrm{L}^{-1} \mathrm{Mg}+0.1 \mathrm{mg} \mathrm{L}^{-1} \mathrm{Sr}+0.05 \mathrm{mg} \mathrm{L}^{-1} \mathrm{Mn}$ (S2); $0.5 \mathrm{mg} \mathrm{L}^{-1} \mathrm{Ca}+0.05 \mathrm{mg} \mathrm{L}^{-1} \mathrm{Mg}+0.25 \mathrm{mg} \mathrm{L}^{-1}$ $\mathrm{Sr}+0.12 \mathrm{mg} \mathrm{L}^{-1} \mathrm{Mn}(\mathrm{S} 3) ; 0.5 \mathrm{mg} \mathrm{L}^{-1} \mathrm{Ca}+0.05 \mathrm{mg} \mathrm{L}^{-1}$ $\mathrm{Mg}+0.5 \mathrm{mg} \mathrm{L}^{-1} \mathrm{Sr}+0.25 \mathrm{mg} \mathrm{L}^{-1} \mathrm{Mn}$ (S4). The set of 5 solutions (a, b, c, d, and e) within the S1, S2, S3 and S4 groups were spiked with $0 \mathrm{mg} \mathrm{L}^{-1} \mathrm{Ca}, \mathrm{Sr}, \mathrm{Mg}, \mathrm{Mn}$ (a); $0.10 \mathrm{mg} \mathrm{L}^{-1} \mathrm{Ca}$ and $\mathrm{Sr}+0.01 \mathrm{mg} \mathrm{L}^{-1} \mathrm{Mg}+0.05 \mathrm{mg} \mathrm{L}^{-1} \mathrm{Mn}$ (b); $0.25 \mathrm{mg} \mathrm{L}^{-1} \mathrm{Ca}$ and $\mathrm{Sr}+0.025 \mathrm{mg} \mathrm{L}^{-1} \mathrm{Mg}+0.125 \mathrm{mg} \mathrm{L}^{-1} \mathrm{Mn}$ (c); $0.40 \mathrm{mg} \mathrm{L}^{-1} \mathrm{Ca}$ and $\mathrm{Sr}+0.04 \mathrm{mg} \mathrm{L}^{-1} \mathrm{Mg}+0.20 \mathrm{mg} \mathrm{L}^{-1} \mathrm{Mn}(\mathrm{d}) ; 0.50 \mathrm{mg} \mathrm{L}^{-1} \mathrm{Ca}$ and $\mathrm{Sr}+0.05 \mathrm{mg} \mathrm{L}^{-1} \mathrm{Mg}+0.25 \mathrm{mg} \mathrm{L}^{-1} \mathrm{Mn}$ (e). Each set of solutions (a-e) was employed to build up the ISA calibration curves. These curves were used to determine the $\mathrm{Ca}$ and $\mathrm{Mg}$ concentrations in each subsample ( $\mathrm{S} 1-\mathrm{S} 4)$.

After optimization, the proposed ISA method was applied to the determination of $\mathrm{Ca}$ and $\mathrm{Mg}$ in five biodiesel samples. The method's accuracy was checked by analyzing nine CRMs. The performance of the ISA method was also assessed by determining $\mathrm{Ca}$ and $\mathrm{Mg}$ in all samples and CRMs by ES, SA and IS as comparative calibration methods.

ES calibration curves were built up by measuring absorbances $(A)$ of analytical solutions (0.1-1.0 $\mathrm{mg} \mathrm{L}^{-1} \mathrm{Ca}$; and $0.01-0.10 \mathrm{mg} \mathrm{L}^{-1} \mathrm{Mg}$ ) and plotting $\mathrm{A}^{\mathrm{Ca}}$ versus [Ca], or $\mathrm{A}^{\mathrm{Mg}}$ versus $[\mathrm{Mg}]$. All solutions were prepared in $1 \%(v / v) \mathrm{HNO}_{3}$ and $0.1 \%(m / v)$ La.

For IS calibration, all blanks, analytical solutions $\left(0.1-1 \mathrm{mg} \mathrm{L}^{-1} \mathrm{Ca}\right.$ and $0.01-0.1 \mathrm{mg} \mathrm{L}^{-1} \mathrm{Mg}$ ) and samples were spiked with $0.25 \mathrm{mg} \mathrm{L}^{-1}$ $\mathrm{Mn}+0.5 \mathrm{mg} \mathrm{L}^{-1} \mathrm{Sr}+0.1 \%(\mathrm{~m} / \mathrm{v}) \mathrm{La}$, and acidified to $1 \%(v / v) \mathrm{HNO}_{3}$. Calibration curves were built up by plotting absorbance ratio $A^{\mathrm{Ca}} / \mathrm{A}^{\mathrm{Sr}}$ versus [Ca], or $\mathrm{A}^{\mathrm{Mg}} / \mathrm{A}^{\mathrm{Mn}}$ versus $[\mathrm{Mg}]$.

The SA calibration solutions were prepared in order to contain 0.0-0.1-0.2-0.3-0.4-0.5 mg L ${ }^{-1} \mathrm{Ca}+0.0-0.01-0.02-0.03-0.04-$ $0.05 \mathrm{mg} \mathrm{L}{ }^{-1} \mathrm{Mg}+10 \%(\mathrm{~m} / \mathrm{v})$ of biodiesel, $0.1 \%(v / v) \mathrm{HNO}_{3}, 0.1 \%$ $(\mathrm{m} / \mathrm{v})$ La. SA calibration curves were built up by plotting absorbance of $\mathrm{Ca}$ and $\mathrm{Mg}$ versus [Ca] and $[\mathrm{Mg}$ ] added, respectively.

ISA calibration comprised six solutions (0.0-0.1-0.2-0.3-0.4$0.5 \mathrm{mg} \mathrm{L}^{-1} \mathrm{Ca}, \mathrm{Sr} ; 0.0-0.01-0.02-0.03-0.04-0.05 \mathrm{mg} \mathrm{L}^{-1} \mathrm{Mg}$; and $\left.0.0-0.05-0.10-0.15-0.20-0.25 \mathrm{mg} \mathrm{L}^{-1} \mathrm{Mn}\right)$ containing $10 \%(\mathrm{~m} / \mathrm{v})$ of biodiesel, $0.1 \%(v / v) \mathrm{HNO}_{3}$, and $0.1 \%(\mathrm{~m} / \mathrm{v})$ La. ISA calibration curves were built up from the absorbance ratio $\mathrm{A}^{\mathrm{Ca}} / \mathrm{A}^{\mathrm{Sr}}$ versus $1 /$ [Sr], or $\mathrm{A}^{\mathrm{Mg}} / \mathrm{A}^{\mathrm{Mn}}$ versus $1 /[\mathrm{Mn}]$.

Accuracy and precision were evaluated by means of addition and recovery tests for biodiesel samples spiked with $0.2 \mathrm{mg} \mathrm{L}^{-1} \mathrm{Ca}$ and $0.1 \mathrm{mg} \mathrm{L}^{-1} \mathrm{Mg}$.

\section{Results and discussion}

\subsection{Evaluation of Sr and Mn as internal standards}

Considering $\mathrm{Sr}$ and $\mathrm{Mn}$ had been used as internal standards for $\mathrm{Ca}$ [12] and $\mathrm{Mg}$ [13-15], respectively, they were selected to be applied in the present study. The ability of Sr and Mn to minimize absorbance fluctuations caused by small variations in atomization conditions was then checked. The effect of variations in the acetylene flow-rate on 
Table 2

Results in $\mathrm{mg} \mathrm{kg}^{-1}$ (expressed as mean \pm standard deviation) for Ca and Mg determined $(n=3)$ in biodiesel samples by ES, IS, SA and ISA.

\begin{tabular}{|c|c|c|c|c|c|c|c|c|}
\hline \multirow[t]{2}{*}{ Samples } & \multicolumn{4}{|l|}{$\mathrm{Ca}\left(\mathrm{mg} \mathrm{kg}^{-1}\right)$} & \multicolumn{4}{|l|}{$\operatorname{Mg}\left(\mathrm{mg} \mathrm{kg}^{-1}\right)$} \\
\hline & ES & IS & SA & ISA & ES & IS & SA & ISA \\
\hline B1 & $1.59 \pm 0.44$ & $0.70 \pm 0.01$ & $0.77 \pm 0.06$ & $0.69 \pm 0.03$ & $>0.05$ & $>0.05$ & $>0.05$ & $>0.05$ \\
\hline B2 & $2.34 \pm 0.56$ & $1.00 \pm 0.11$ & $1.15 \pm 0.04$ & $1.13 \pm 0.04$ & $>0.05$ & $>0.05$ & $>0.05$ & $>0.05$ \\
\hline B3 & $2.33 \pm 0.70$ & $1.01 \pm 0.16$ & $1.19 \pm 0.15$ & $1.05 \pm 0.10$ & $>0.05$ & $>0.05$ & $>0.05$ & $>0.05$ \\
\hline B4 & $2.80 \pm 0.28$ & $1.17 \pm 0.13$ & $1.28 \pm 0.13$ & $1.20 \pm 0.04$ & $0.128 \pm 0.004$ & $0.108 \pm 0.003$ & $0.120 \pm 0.007$ & $0.110 \pm 0.002$ \\
\hline B5 & $3.22 \pm 0.23$ & $1.39 \pm 0.14$ & $1.57 \pm 0.11$ & $1.46 \pm 0.06$ & $0.125 \pm 0.016$ & $0.112 \pm 0.003$ & $0.121 \pm 0.006$ & $0.116 \pm 0.004$ \\
\hline
\end{tabular}

absorbance of $\mathrm{Ca}, \mathrm{Sr}, \mathrm{Mg}$ and $\mathrm{Mn}$ is shown in Fig. 2. As it can be seen, the $\mathrm{Ca}-\mathrm{Sr}$ and $\mathrm{Mg}-\mathrm{Mn}$ pairs were similarly affected. These similar behaviors confirm that $\mathrm{Sr}$ and $\mathrm{Mn}$ are adequate internal standards for $\mathrm{Ca}$ and $\mathrm{Mg}$, respectively [12-15]. An increase in $\mathrm{Ca}$ and $\mathrm{Sr}$ absorbances with increasing acetylene flow-rates was observed up to $110 \mathrm{~L} \mathrm{~h}^{-1}$ (Fig. 2a); for $\mathrm{Mg}$ and Mn, absorbances increased up to $120 \mathrm{~L} \mathrm{~h}^{-1}$ (Fig. 2b). Higher acetylene flow-rates cause an increase in the concentration of carbon in the flame (reducing flame), contributing to a higher rate of the generic reaction $\mathrm{MO}+\mathrm{C} \rightarrow \mathrm{M}+\mathrm{CO}$, which results in a higher concentration of the analytes (M) in the flame [16].

The use of internal standards minimized variations in absorbance for $\mathrm{Ca}$ and $\mathrm{Mg}$ as acetylene flow-rates varied between 70 and $120 \mathrm{~L} \mathrm{~h}^{-1}$, and between 40 and $80 \mathrm{~L} \mathrm{~h}^{-1}$, respectively (Fig. 2a and b). The efficiency of Sr and $\mathrm{Mn}$ as internal standards may be explained in terms of atomization mechanisms: $\mathrm{Ca}, \mathrm{Sr}, \mathrm{Mg}$ and $\mathrm{Mn}$ atomization essentially occurs via MO formation ( $\mathrm{M}=\mathrm{Ca}, \mathrm{Mg}, \mathrm{Sr}, \mathrm{Mn}$ ), and the $\mathrm{MO}$ dissociation energies for the $\mathrm{Ca}-\mathrm{Sr}$ (CaO: $363.3 \pm 50 \mathrm{~kJ} \mathrm{~mol}^{-1}$; SrO: $426.3 \pm 6.3 \mathrm{~kJ} \mathrm{~mol}^{-1}$ ) and the Mg-Mn (MgO: $358.2 \pm 7.2 \mathrm{~kJ} \mathrm{~mol}^{-1}$; $\mathrm{MnO}: 362 \pm 25 \mathrm{~kJ} \mathrm{~mol}^{-1}$ ) pairs are similar [17].

The ethanol employed to dilute biodiesel samples (strategy adopted for sample preparation) may alter atomization conditions, thus, the effect of the ethanol content on the absorbance of $\mathrm{Ca}, \mathrm{Mg}$, Mn and $\mathrm{Sr}$ was also evaluated. An increase in the $\mathrm{Ca}$ and $\mathrm{Sr}$ absorbance at higher ethanol concentrations (Fig. 3a) was observed. This may be attributed to a decrease in the solutions surface tension [18], and an increase in the flame temperature [19], which respectively improves nebulization and $\mathrm{Ca}$ and $\mathrm{Sr}$ atomization rates. A slight decrease in $\mathrm{Mg}$ and $\mathrm{Mn}$ absorbance was observed (Fig. 3b) when the ethanol-water ratio varied from 0 to $40 \%(v / v)$. Ethanol content higher than $40 \%(v / v)$ increased the absorbance signals. It should be mentioned that the effect of flame temperature on both $\mathrm{Mg}$ and $\mathrm{Mn}$ was less pronounced than that observed for $\mathrm{Ca}$ and $\mathrm{Sr}$. This fact may be related to the lower energy requirements to dissociate $\mathrm{MgO}$ and $\mathrm{MnO}$. As it can be seen in Fig. 2, the effects on Ca and $\mathrm{Mg}$ absorbance caused by variations in the acetylene flow-rate between 70 and $90 \mathrm{~L} \mathrm{~h}^{-1}$ and 40 and $80 \mathrm{~L} \mathrm{~h}^{-1}$, respectively, were minimized by using IS ( $\left.A^{\mathrm{Ca}} / \mathrm{A}^{\mathrm{Sr}} \mathrm{A}^{\mathrm{Mg}} / \mathrm{A}^{\mathrm{Mn}}\right)$. This is additional evidence of the efficiency of Sr and Mn as internal standards for Ca and Mg, respectively.

\subsection{Evaluation of the internal standard concentrations}

Considering that each internal standard may be present in the original samples at different concentration ranges, the effect of their concentration on the efficiency of the ISA method was evaluated. Calcium and Mg were determined in samples spiked with $0.5 \mathrm{mg} \mathrm{L}^{-1} \mathrm{Ca},+0.05 \mathrm{mg} \mathrm{L}^{-1} \mathrm{Mg}$ and different concentrations of $\mathrm{Mn}\left(0-0.25 \mathrm{mg} \mathrm{L}^{-1}\right)$ and $\mathrm{Sr}\left(0-0.50 \mathrm{mg} \mathrm{L}^{-1}\right)$, as depicted in Fig. 1. Calibration curves associated to additions of Mn and $\mathrm{Sr}$ are shown in Fig. $4 \mathrm{a}$ and b, respectively. For these figures, the absorbance of $\mathrm{Mn}$ and $\mathrm{Sr}$ in solutions 'a' (Fig. 1, first column) for each group S1, S2, S3 and S4 was taken as analytical blank to correct the absorbance of solutions b-e. Net calibration curves are shown in Fig. 4c and d. The absorbances corresponding to the $\mathrm{Mn}$ and $\mathrm{Sr}$ concentrations originally present in the samples (blank) were subtracted from each sample so that 1/ [Mn] or $1 /[\mathrm{Sr}]$ correspond to the exact concentrations of added internal standards. The small sensitivity variations observed for the ISA calibration curves shown in Fig. 4e and f did not negatively impact the recoveries of Ca $(95 \%, 87 \%, 98 \%, 93 \%)$ and $\operatorname{Mg}(90 \%, 112 \%, 100 \%, 97 \%)$. In addition, the presence of $\mathrm{Mn}$ in the original samples did not affect the performance of ISA, as opposed to what was observed for Mg determinations in CRMs by IS (Table 1). These results suggest that the internal standard may be present in the original samples, and that this effect was minimized by the matrix-matching effect provided by the ISA method.

\subsection{Determination of $\mathrm{Ca}$ and $\mathrm{Mg}$}

The accuracy of the ISA method was checked by analyzing diverse CRMs (milk, botanical tissues, biological tissues, flours and biodiesel). For comparative purposes, all CRMs were also analyzed by ES, SA and IS (Table 1 ).

For ES, the results obtained for Ca in Whole Milk Powder and Mussel Tissue, and for $\mathrm{Ca}$ and $\mathrm{Mg}$ in Biodiesel were not in agreement with the certified values at the $95 \%$ of confidence level ( $t$-test). For biodiesel, the Ca concentration determined was 2.5 times higher than the certified value, probably due to the higher flame temperature caused by ethanol used for sample dilution. Magnesium concentration, however, presents recovery of, only, $114 \%$, because the increase in $\mathrm{Mg}$ sensitivity was offset by the decrease in aspiration-rate due to sample viscosity.

For the IS method, all values determined for Ca were in agreement with the certified values at the $95 \%$ confidence level ( $t$-test). For Mg three materials presented lower concentrations than the certified values. As discussed previously, the poor recoveries were probably caused by the presence of Mn in the samples' composition: Mussel Tissue ( $25 \mu \mathrm{g} \mathrm{L}^{-1} \mathrm{Mn}, 87 \%$ of recovery), Rice Flour ( $53 \mu \mathrm{g} \mathrm{L}{ }^{-1} \mathrm{Mn}, 75 \%$ of recovery) and Tomato Leaves ( $98 \mu \mathrm{g} \mathrm{L} \mathrm{L}^{-1} \mathrm{Mn}, 73 \%$ of recovery).

For SA, all values determined in the CRMs were similar to the certified values. However, some results (Ca in Biodiesel and Wheat Flour, and $\mathrm{Mg}$ in Whole Milk Powder) were not in agreement with the certified concentrations at the $95 \%$ confidence level ( $t$-test). The observed results are due to the great handling during solution preparation,

Table 3

Recoveries in \% (expressed as mean \pm standard deviation) corresponding to $0.2 \mathrm{mg} \mathrm{L}^{-1} \mathrm{Ca}$ and $0.1 \mathrm{mg} \mathrm{L}^{-1} \mathrm{Mg}$ determined ( $n=3$ ) by ES, IS, SA and ISA.

\begin{tabular}{|c|c|c|c|c|c|c|c|c|}
\hline \multirow[t]{2}{*}{ Samples } & \multicolumn{4}{|l|}{$\mathrm{Ca}$} & \multicolumn{4}{|l|}{$\mathrm{Mg}$} \\
\hline & ES & IS & SA & ISA & ES & IS & SA & ISA \\
\hline B1 & $234 \pm 27$ & $102 \pm 11$ & $107 \pm 9$ & $94 \pm 2$ & $111 \pm 5$ & $100 \pm 4$ & $111 \pm 2$ & $100 \pm 5$ \\
\hline B2 & $220 \pm 28$ & $107 \pm 15$ & $97 \pm 5$ & $99 \pm 3$ & $119 \pm 8$ & $98 \pm 2$ & $115 \pm 2$ & $105 \pm 2$ \\
\hline B3 & $291 \pm 21$ & $112 \pm 11$ & $121 \pm 8$ & $93 \pm 2$ & $116 \pm 7$ & $105 \pm 3$ & $108 \pm 15$ & $105 \pm 1$ \\
\hline B4 & $219 \pm 11$ & $101 \pm 5$ & $127 \pm 6$ & $109 \pm 4$ & $113 \pm 5$ & $100 \pm 2$ & $113 \pm 2$ & $103 \pm 2$ \\
\hline B5 & $283 \pm 76$ & $100 \pm 10$ & $127 \pm 10$ & $109 \pm 5$ & $120 \pm 7$ & $104 \pm 3$ & $106 \pm 17$ & $106 \pm 6$ \\
\hline
\end{tabular}


Table 4

Comparative data for $\mathrm{Ca}$ and $\mathrm{Mg}$ determination in one biodiesel sample by HR-CS FAAS employing external standard (ES), internal standardization (IS), standard addition (SA) and internal standard addition (ISA).

\begin{tabular}{|c|c|c|c|c|c|}
\hline & & ES & IS & SA & ISA \\
\hline \multirow[t]{3}{*}{ Calibration } & Number of standard solutions ${ }^{a}$ & 6 & 6 & 6 & 6 \\
\hline & Time spent preparing standard solutions, min & 5 & 6 & 11 & 12 \\
\hline & Time spent measuring standard solutions, min & 12 & 18 & 12 & 18 \\
\hline \multirow[t]{4}{*}{ Sample } & Number of sample analyzed & 1 & 1 & 1 & 1 \\
\hline & Sample mass by replicate, $g$ & 1 & 1 & 6 & 6 \\
\hline & Time spent preparing sample, min & 2 & 2 & 0 & 0 \\
\hline & Time spent measuring sample, min & 2 & 3 & 0 & 0 \\
\hline \multirow[t]{4}{*}{ Determination } & Time spent determining $(n=1) \mathrm{Ca}$ and $\mathrm{Mg}$, min & 21 & 29 & 23 & 30 \\
\hline & Time spent determining $(n=2) \mathrm{Ca}$ and $\mathrm{Mg}$, min & 25 & 34 & 46 & 60 \\
\hline & Time spent determining $(n=3)$ Ca and Mg, min & 29 & 39 & 69 & 90 \\
\hline & Time spent determining $(n=4) \mathrm{Ca}$ and $\mathrm{Mg}$, min & 33 & 44 & 92 & 120 \\
\hline
\end{tabular}

a Six-point calibration (blank +5 standards).

making the SA method more susceptible to random errors, which can affect the results.

For the ISA method, all determined values for both Ca and Mg were in agreement with the certified ones at the $95 \%$ confidence level ( $t$-test). ISA's relative standard deviations (RSD) of $6 \%$ for Ca and Mg were better than the ones calculated for ES (12\% for Ca and 9\% for $\mathrm{Mg}$ ), IS ( $9 \%$ for $\mathrm{Ca}$ and $7 \%$ for $\mathrm{Mg}$ ) and SA ( $7 \%$ for $\mathrm{Ca}$ and $8 \%$ for $\mathrm{Mg}$ ). The negative effects on accuracy and precision caused by random errors, analytical fluctuations due to physical-chemical parameters (i.e., flame composition and rate of sample introduction), and the presence of $\mathrm{Mn}$ in some samples were significantly minimized by the combination of internal standardization and standard additions with ISA

Following the method validation, ISA was applied to the determination of $\mathrm{Ca}$ and $\mathrm{Mg}$ in five biodiesel samples. The same samples were also analyzed by ES, IS and SA for comparison. As it can be seen in Table 2, the results follow the same tendency observed for the biodiesel CRM. The concentrations of $\mathrm{Ca}$ and $\mathrm{Mg}$ obtained by ISA were in agreement with those determined by IS and SA at the $95 \%$ confidence level (paired $t$ test). However, results for ES were statistically different from the other calibration methods.

As observed in the previous accuracy studies, addition and recovery studies have shown the following efficiency order: ES $<$ SA $<$ IS, ISA (Table 3). Analysis of this table reveals that better results (precision and accuracy) were obtained with ISA method. RSDs calculated for 12 successive measurements of a sample containing $0.5 \mathrm{mg} \mathrm{L}^{-1} \mathrm{Ca}$ and $0.05 \mathrm{mg} \mathrm{L}^{-1} \mathrm{Mg}$ were: as $12 \%, 10 \%, 7 \%$ and $3 \%$ for ES, IS, SA and ISA, respectively for Ca; and 6\%, 3\%, 7\% and 3\% for ES, IS, SA and ISA, respectively for Mg. The precision of ISA is comparable to other classical strategies of calibration (ES, SA, IS). On the other hand, the proposed ISA method demands more time and sample amount (Table 4) than the classical comparative methods. Considering the determination of $\mathrm{Ca}$ and $\mathrm{Mg}$ in one biodiesel sample by HR-CS FAAS, the spent times for 1 replicate were 21, 29, 23 and 30 min for ES, IS, SA and ISA, respectively. The long time observed for IS and ISA is a consequence of measuring 4 wavelengths ( 2 analytes +2 internal standards). Analysis of Table 4 also reveals that when the number of replicates increased from $n=1$ to $n=4$, the total time for determining $\mathrm{Ca}$ and $\mathrm{Mg}$ by ES, IS, SA and ISA increased $1.5,1.5,4$ and 4 times, respectively. This is a consequence of using one calibration per sample (SA and ISA) and one calibration for several samples (ES and IS). In spite of the lower sample throughput, the ISA may be considered an interesting and efficient tool to analyzed complex samples.

\section{Conclusions}

The ISA calibration method is an efficient and attractive strategy that combines the benefits of IS and SA. Different from the traditional SA calibration, ISA also corrects for random errors and analytical signal fluctuations. In addition, the presence of the internal standard in the original sample at relatively low concentrations should not affect the ISA performance as would be the case in a traditional IS determination. On the other hand, it is noteworthy to point out that sample volume and number of analytical solutions employed are some drawbacks of ISA. However, these issues can be minimized by using Standard Dilution Analysis coupled to flow technique.

\section{Acknowledgments}

The authors would like to thank the Conselho Nacional de Desenvolvimento Científico e Tecnológico-CNPq, for financially supporting this work (grants 471453/2013-7 and 303255/2013-7). The fellowships provided to M.A.B by the CNPq and to F.M.F. by the São Paulo Research Foundation-FAPESP (2012/23323-7) are also greatly appreciated. We would also like to thank the Monitoring and Research Center for Fuel Quality, Biofuels, Oil and Derivatives-CEMPEQC for providing the biodiesel samples.

\section{References}

[1] D.A. Skoog, D.M. West, F.J. Holler, Fundamentals of Analytical Chemistry, 6th ed. Saunders College Pub., Fort Worth, 1992. (892 pp.)

[2] G.D. Christian, P.K. Dasgupta, K.A. Schug, Analytical Chemistry, Wiley, New York, 2014. (826 pp.).

[3] L. Cuadros-Rodríguez, L. Gámiz-Gracia, E.M. Almansa-López, J.M. Bosque-Sendra, Calibration in chemical measurement processes. II. A methodological approach, Trends Anal. Chem. 20 (2001) 620-636.

[4] L.H.J. Lajunen, P. Perämäki, Spectrochemical Analysis by Atomic Absorption and Emission, 2nd ed. Royal Society of Chemistry, Cambridge, 2004. (342 pp.).

[5] W.B. Barnett, V.A. Fassel, R.N. Kniseley, Theoretical principles of internal standardization in analytical emission spectroscopy, Spectrochim. Acta B 23 (1968) 643-664.

[6] Z. Mester, R.E. Sturgeon, Sample Preparation for Trace Element Analysis, 1st ed. Elsevier, Boston, 2003. 79-81.

[7] A.C. Davis, B.W. Alligood, C.P. Calloway Jr., B.T. Jones, Direct determination of cadmium in urine by electrothermal vaporizer-inductively coupled plasma analysis using a tungsten coil vaporizer, Appl. Spectrosc. 59 (2005) 1300-1305.

[8] E.D. Salin, M. Antler, G. Bort, Evaluation of the simultaneous use of standard additions and internal standards calibration techniques for inductively coupled plasma mass spectrometry, J. Anal. At. Spectrom. 19 (2004) 1498-1500.

[9] W.B. Jones, G.L. Donati, C.P. Calloway Jr., B.T. Jones, Standard dilution analysis, Anal. Chem. 87 (2015) 2321-2327.

[10] M.R.L. Magalhães, A.I. Barros, A.P. Oliveira, A. Santos, Dissolution in ethanol as a sample preparation procedure for determination of metals in biodiesel by FAAS, Curr. Anal. Chem. 10 (2014) 166-171.

[11] E.S. Chaves, M.T.C. Loos-Vollebregt, A.J. Curtius, F. Vanhaecke, Determination of trace elements in biodiesel and vegetable oil by inductively coupled plasma optical emission spectrometry following alcohol dilution, Spectrochim. Acta B 66 (2011) 733-739.

[12] A. Batho, C. Philips, Simultaneous determination of calcium and magnesium dual channel atomic absorption spectrometry, Lab. Pract. 38 (1989) 70.

[13] G.R. Dulude, J.J. Sotera, H.L. Kahn, Determination of calcium in cement by flame atomic absorption spectrometry with strontium as an internal standard, Anal. Chem. 53 (1981) 2100-2102.

[14] T. Takada, K. Nakano, Internal standard method in flame atomic absorption spectrometry, Spectrochim. Acta B 36 (1981) 735-745.

[15] F.J. Feldman, Internal standardization in atomic emission and absorption spectrometry, Anal. Chem. 42 (1970) 719-724.

[16] J. Komárek, L. Sommer, Organic complexing agents in atomic absorption spectrometry-a review, Talanta 29 (1982) 159-166.

[17] D.R. Lide (Ed.), CRC Handbook of Chemistry and Physics, 88th ed.CRC Press, Boca Raton, 2008.

[18] F.R.P. Rocha, J.A. Nóbrega, Effects of solution physical properties on copper and chromium signals in flame atomic absorption spectrometry, J. Chem. Educ. 73 (1996) 982-984

[19] K. Szivós, Application of organic solvents in atomic-absorption spectrophotometry, Period. Polytech. Chem. 25 (1981) 121-132. 